\title{
Retraction Note: Exosomes from glioma cells induce a tumor-like phenotype in mesenchymal stem cells by activating glycolysis
}

Zhanjun Ma ${ }^{1}$, Xue Cui ${ }^{2}$, Li Lu ${ }^{3,4,5^{*}}$, Guohu Chen ${ }^{2}$, Yang Yang ${ }^{1}$, Yan Hu${ }^{6}$, Yubao Lu' ${ }^{1}$ Zhangqi Cao ${ }^{6}$, Yan Wang ${ }^{6}$ and Xuexi Wang ${ }^{7,8,9^{*}}$

Retraction Note: Stem Cell Res Ther 10, 60 (2019)

https://doi.org/10.1186/s13287-019-1149-5

The authors have retracted this article. After publication concerns were raised with respect to the data presented in Figure 11B, Figure 11D and Figure 12A. As the authors no longer have access to the original data they have decided to retract this article. All authors agree with this retraction.

\begin{abstract}
Author details
'The Second Clinical Medical College, Lanzhou University, Lanzhou 730000, Gansu, China. ${ }^{2}$ The First Clinical Medical College, Lanzhou University, Lanzhou 730000, Gansu, China. ${ }^{3}$ Institute of Pharmacology, School of Basic Medical Science, Lanzhou University, Lanzhou 730000, Gansu, China. ${ }^{4}$ Key Laboratory of Preclinical Study for New Drugs of Gansu Province, Lanzhou 730000, Gansu, China. ${ }^{5}$ School of Basic Medical Sciences of Lanzhou University, School of Medicine, 205 Tianshui Rd South, Lanzhou 730000 Gansu, China. ${ }^{6}$ School of Basic Medical Sciences, Lanzhou University, Lanzhou 730000, Gansu, China. ' 'School of Basic Medical Sciences, Lanzhou University, Lanzhou 730000, Gansu, China. ${ }^{8}$ Key Laboratory of Preclinical Study for New Drugs of Gansu Province, Lanzhou 730000, Gansu, China. ${ }^{9}$ School of Basic Medical Sciences of Lanzhou University, School of Medicine, 205 Tianshui Rd South, Lanzhou 730000, Gansu, China.
\end{abstract}

Published online: 14 April 2021

The original article can be found online at https://doi.org/10.1186/s13287019-1149-5.

* Correspondence: Iul@|zu.edu.cn; wangxuexi@|zu.edu.cn

${ }^{3}$ Institute of Pharmacology, School of Basic Medical Science, Lanzhou University, Lanzhou 730000, Gansu, China

${ }^{7}$ School of Basic Medical Sciences, Lanzhou University, Lanzhou 730000, Gansu, China

Full list of author information is available at the end of the article

(c) The Author(s). 2021 Open Access This article is licensed under a Creative Commons Attribution 4.0 International License, which permits use, sharing, adaptation, distribution and reproduction in any medium or format, as long as you give appropriate credit to the original author(s) and the source, provide a link to the Creative Commons licence, and indicate if changes were made. The images or other third party material in this article are included in the article's Creative Commons licence, unless indicated otherwise in a credit line to the material. If material is not included in the article's Creative Commons licence and your intended use is not permitted by statutory regulation or exceeds the permitted use, you will need to obtain permission directly from the copyright holder. To view a copy of this licence, visit http://creativecommons.org/licenses/by/4.0/. The Creative Commons Public Domain Dedication waiver (http://creativecommons.org/publicdomain/zero/1.0/) applies to the data made available in this article, unless otherwise stated in a credit line to the data. 